\title{
Implementation of Regulation of Banjar Regent Number 8 of 2016 Concerning Reducing the Use of Plastic Bags in Banjar District
}

Eka Yusnitawati*, Asmu'i, Budi Suryadi

Master of Governmental Science, Faculty of Social and Political Science, Lambung Mangkurat University, Banjarmasin, Indonesia

DOI: $10.36348 /$ sijlcj.2021.v04i02.012 $\quad$ | Received: 08.02.2021 | Accepted: 22.02.2021 | Published: 26.02 .2021

*Corresponding author: Eka Yusnitawati

\section{Abstract}

Banjar Regency through the Banjar Regent Regulation No. 8/2016 on reducing the Use of Plastic Bags is the first Regency to make arrangements to reduce the use of plastic bags. However, after the implementation of the Perbup, there has been no significant change to the accumulation of plastic waste in Banjar Regency. In fact, plastic waste takes a very long time to decompose, so it has a bad impact on the environment for a long time. This shows the need for a study on the effectiveness of Perbup. This study aims to analyze the effectiveness of Perbup on reducing the use of plastic bags. The type of research used is qualitative with an exploratory method through an inductive approach. Data collection techniques are carried out through observation, interviews, and documentation. Observations were made at the Final Disposal Site (TPA), 23 modern market places, and 14 local traditional market places. The results showed that the implementation of Perbup has not been effective in reducing the use of plastic bags, and has not been optimal because it is still in the socialization and supervision stages. There has been no firm action in the form of fines or sanctions for violators of these regulations.

Key words: Banjar Regency; Regent Regulation; Reduction of Plastic Bags.

Copyright (C) 2021 The Author(s): This is an open-access article distributed under the terms of the Creative Commons Attribution 4.0 International License (CC BY-NC 4.0) which permits unrestricted use, distribution, and reproduction in any medium for non-commercial use provided the original author and source are credited.

\section{INTRODUCTION}

Environmental issues are very broad and can even be divided into three categories, namely local environmental issues, national environmental issues, and global environmental issues. Some examples of local environmental issues include drought, floods, landslides, coastal erosion, and seawater intrusion. National environmental issues can be in the form of forest fires and offshore oil pollution, while global environmental issues, for example, include global warming, depletion of the ozone layer, acid rain, population growth, desertification, decreasing biodiversity, and pollution of B3 waste (Hazardous and Toxic Materials). The categories are divided based on the size and extent of the impact. However, environmental problems that occur are interrelated and affect one another. for example, offshore waste pollution which is part of B3 waste pollution as well as forest fires which are a factor in the depletion of the ozone layer and global warming.

Environmental problems are difficult to solve for three reasons. First, science or knowledge of complex environmental problems because there are many dynamic systems that are interconnected. Second, many stakeholders are involved as both causes and solutions to environmental problems. Arranging all stakeholders to act in coordination with the rules becomes difficult. Third, solving global environmental issues needs to change the consumption and pollution of human natural resources, which means changing lifestyles.

One of the causes of environmental problems is community waste, especially non-organic such as plastic. Non-organic waste is more dangerous and has a big impact on the environment because it is difficult to decompose by the soil and even takes hundreds to thousands of years to break down. Moreover, plastic waste will only break down into small fragments that settle on the ground. Plastic is a synthetic polymer material that is made through a polymerization process which cannot be separated from our daily lives which we can generally find in various forms of packaging or its use in electrical appliances and household appliances. Global use of plastic products worldwide is estimated at 260 million tonnes in 2008. For more than 50 years, global plastic production and consumption has continued to increase. An estimated 299 million tons of 
Eka Yusnitawati et al., Sch Int J Law Crime Justice, Feb, 2021; 4(2): 110-116

plastic were produced in 2013. According to the 2013 Global Industry Analysis report, the world's use of plastic products reached 297 tons at the end of 2017.

Indonesia enters the second rank by contributing 83 percent $(83 \%)$ of waste to the world each year [1]. There is no accurate data on the amount of pollution caused by plastic waste in Indonesia, although some estimates have been made. Based on these problems and the absence of optimal follow-up from the provincial government, Banjar Regency has taken action to reduce the use of plastic bags in the form of Banjar Regent Regulation Number 8 of 2016 concerning Reducing the Use of Plastic Bags which came into effect on February 9, 2016, and is listed as the first Regency to make these rules.

Martapura as the capital of Banjar Regency is one of the cities in Indonesia that is experiencing problems using plastic shopping bags. The use of plastic shopping bags among the community is difficult to control; this is due to various shops that provide services in the form of free plastic shopping bags. According to Sununianti [2] plastic waste takes a long time to be decomposed by nature, besides plastic waste will cause various kinds of pollution that damage the environment. The properties of this plastic material result in an increase in the production of plastic waste from year to year. As an illustration, plastic consumption in Indonesia reaches $10 \mathrm{~kg}$ per capita per year, so that it can be predicted that the amount of plastic waste produced is.

Head of the Banjar Regency Environmental Service, Boyke W Triestiyanto [3] said that waste management in Banjar Regency was centered on the Cahaya Kencana TPA which began operating in 2002 with an area of 6.5 hectares and had exceeded its capacity so that the Cahaya Kencana TPA was expanded to 28 hectares and 16 hectares have been used with 86884 tonnes of waste in 2018. Head of the Cahaya Kencana TPA Regional Technical Implementation Unit (UPTD), Adi Winoto, SE [4], said that the waste that enters the Cahaya Kencana TPA every day on average is 115 tons and produces $20 \mathrm{~m} 3$ of methane gas. The methane gas produced at the Cahaya Kencana TPA serves approximately $100 \mathrm{k}$, with an average use of methane gas perKK of $10 \mathrm{~kg} / \mathrm{KK} /$ per month.

Seeing the problems that occur in the increase in the generation of plastic waste, especially those caused by the use of plastic shopping bags in Banjar Regency, this research was conducted with the aim of determining the right strategy to overcome this problem. The research will be conducted in Banjar Regency, South Kalimantan Province, because it has the second highest volume of waste per day among other districts in South Kalimantan. The main data that becomes the material is the waste management policy document in Banjar Regency which is currently still valid, namely the Banjar Regency Regional Regulation Number 4 of 2016 and the Banjar Regency Regulation Number 8 of 2018 concerning Reducing the Use of Plastic Bags. In addition, other secondary data are used to enrich information, namely research results and statistical reports. The analysis in this study uses an approach. The method used is a qualitative approach.

\section{METHOD}

The design in the research method used is a qualitative research method. This study uses an exploratory method with an inductive approach to obtain data. Reasoning using the induction method is the researcher's way of thinking in drawing general conclusions from individual cases. Researchers use the data search method by examining the description of the object of research in general, this is because in conducting research it is required to see the real conditions directly in the field. The data collected is divided into two, namely primary data and secondary data. Premiere data to validate existing, secondary data in the form of data from documentation either through photos, memos or important letters as well as local laws and regulations implemented by the Environmental Agency of Banjar Regency. Data collection techniques are carried out through observation, interviews, and documentation. Observations were made at the Final Disposal Site (TPA), 23 modern market places, and 14 local traditional market places. The analysis consists of three activity streams that occur simultaneously, namely: data reduction, data presentation, drawing conclusions/verification.

\section{RESULTS AND DISCUSSION}

In implementing the implementation of the Banjar Regent Regulation Number 8 of 2016 concerning Reducing the Use of Plastic Bags in Banjar Regency, so that the regent's regulation can be known and implemented by the community. The duties and responsibilities of local governments in reducing the use of plastic bags in Banjar Regency are based on the Banjar Regent Regulation No. 8 of 2016 article 7 chapter IV regarding the rights and obligations of local governments, namely:

\section{Socialization \\ 2. Supervision \\ 3. Become a facilitator \\ 4. Conducting coach}

Further details on the government's duties and responsibilities in reducing the use of plastic bags in Banjar Regency are as follows:

\section{Socialization}

According to Jack Levin and James L. Spates, quoted from the gurupend Pendidikan.com page, socialization is a process of cultural inheritance and 
Eka Yusnitawati et al., Sch Int J Law Crime Justice, Feb, 2021; 4(2): 110-116

institutionalization into individual personalities. Socialization is also a process of cultivating habits, values and rules from one generation to another in a community group. These values or rules are the same as the Banjar Regent Regulation No. 8 of 2016 concerning Reducing the Use of Plastic Bags, so that all levels of Banjar Regency society know about these regulations, socialization is needed to be the first step in policy implementation.

The socialization phase has been carried out since mid-2019 by the Environmental Service of Banjar Regency, namely the Waste Management and Transportation Section in the Waste Management, Gardening and Waste Management Sector. The socialization activities in 2019 were carried out 10 times in various modern shops. The socialization team consists of 7 people plus 1 head of the field, where the socialization is carried out alternately by each staff but still accompanied by the head of the field. To support the socialization process, the facilities used are official cars intended to visit each modern shop.

Interview with Mr. Ahmad Norsailah, SST Head of Waste Management, Landscaping and Waste Management of the Environmental Service of Banjar Regency (Head of the Banjar Regency Environmental Service) said:

"We do the dissemination of this workshop in a push to bam, that is, the socialization team visits each of the modern shops in Banjar Regency. There are approximately 10 modern shops that we provide socialization and various responses. For direct socialization to the public, I haven't, but we have tried to advertise it on regional TV and radio"(interview: 11 November 2020).

According to the Head of the District Environment Office. Banjar, after the socialization, Indogrosir immediately went to the office of the Environmental Service Office of Banjar Regency to show that the plastic bags they are using are environmentally friendly plastic bags because they are easily biodegradable and have passed the test and have obtained certificates. In addition, modern stores such as Alfamart and Indomaret, through their respective branch leaders, took the initiative to implement this policy by assigning their employees to inform consumers that they no longer provide free plastic bags, even Indomaret made a policy to no longer provide plastic bags. To consumers.

Dissemination conducted by the Head of the District Environmental Service. Banjar throughout mid2019 can only be done in 10 modern shops and has not conducted outreach to the public directly. This is because the Head of the Environmental Service Office of Banjar Regency is still hesitant to apply the regulation so that it has an impact on the socialization process. Head of the District Environmental Service. Banjar explained:

"We are still not doing this intensively, because the head of the Kadis said that it is necessary to revise this regulation first. As you can see in the news too, if he is still half-hearted to implement this rule. If we look at the current era, plastic has become a habit for our society, so maybe there will be many pros and cons from the community"(Interview: 11 November 2020).

Regarding the socialization that was carried out on National Waste Care Day 2019, the Head of the District Environmental Service. Banjar confirmed that the activity was an initiative of PD Pasar Bauntung Batuah to inform the public to reduce the use of plastic bags because it could damage the environment and to preserve the use of baskets when they went shopping at the market.

When conducting interviews with several public and modern store employees, some of them knew about the existence of these regulations but did not know the contents of the regulations. The following are some of the results of interviews from the community's side of Banjar Regency regarding their knowledge of the Banjar Regent Regulation No. 8 of 2016:

Interview with Mr. A, a visitor to Alfamart, Kertak District, Hanyar said:

"I already know the policy, I got the news from the news broadcast on Banjar TV. Rich in Duta TV and Banjar TV. In essence, he said in the regulation the goal is to reduce the use of plastics so as not to pollute the environment"(interview: 11 November 2020).

Interview with Mrs. L, the community of Peat District said:

"I don't know if there is such a policy, the government has not yet had socialization. Traders like me also rarely see the news so I don't know"(interview: 13 November 2020).

An interview with Ms. G, the community of Martapura Kota District said:

"Yes, I know when I went shopping to Indomaret, I didn't provide plastic bags anymore. As for what I know, the regulation is only about the prohibition of using plastic bags in markets, modern stores like Alfamart, Indomart, supermarkets, minimarkets or supermarkets. I don't know for the details"(interview: 9 November 2020).

Meanwhile, knowledge from the modern shop side was based on an interview with Mrs. S, the staff of the Order Department of the Eva LF Minimarket, Kertak Hanyar District, said: 
Eka Yusnitawati et al., Sch Int J Law Crime Justice, Feb, 2021; 4(2): 110-116

"Yes, I know about the policy from reading and reading on the internet, but for the content I don't know and have not read the contents, just have a glimpse if, for example, the government issued the policy. The government is also here only to tell koko who owns this shop, we don't have it"(interview: 11 November 2020).

Then, an interview with Mrs. A, the Head of the Alfamart Store, Gambut District said:

"I already know that if the government has made a regulation on reducing plastic bags, it just so happens that our direct supervisor told us. But I haven't read the contents yet, so I don't really know"(interview: 13 November 2020).

Interview with Mrs. R Kasir Indomaret Martapura Kota District said:

"You already know, someone from the office told you if there is a regulation and we have implemented it from October 2019. The policy is basically aimed at reducing plastic waste"

Based on the results of interviews with the public and modern shops, it was found that the socialization carried out by the government was not optimal, because some people and modern shops did not know clearly the contents of these regulations.

The local government is targeting that in 2020, it will work harder to socialize this regulation so that it can be known by all levels of society in Banjar Regency. This is in accordance with the statement of the Head of the Environmental Office of the District. Banjar who said:

"In 2020 we will try even more to disseminate the regulations for reducing plastic bags, the plan is that in every event or event that will be carried out by the service, we will also introduce socialization about the regulation" (interview: 11 November 2020).

\section{Supervision}

In addition to providing socialization related to the Banjar Regent Regulation No. 8 of 2016 concerning Reducing the Use of Plastic Bags, the government also oversees modern shops in Banjar Regency. Supervision is a form of action by local governments to inspect, control and even warn modern shops in order to reduce the use of plastic bags.

This supervisory task is carried out by the Environmental Monitoring Section in the Pollution and Environmental Damage Control Section, Environmental Service of Banjar Regency. The supervisory team consists of 7 people consisting of 6 staff and 1 head of section. The formation of this supervisory team did not go through special recruitment but directly appointed sections that already exist in the Banjar Regency
Environmental Service according to their duties and authorities, appointed based on regional regulations.

The implementation of this supervision began in early 2019, when the City of Banjarbaru had implemented the Regulation of the Mayor of Banjarbaru No. 16 of 2016 concerning Reducing the Use of Plastic Bags in the City of Banjarbaru. The Environmental Monitoring Section directly visited several modern shops to check the types of plastic bags they used, but the supervision had not yet reached the stage of reprimand or confiscation because at that time the regulations owned by Banjar District had not been implemented. The results of interviews at the Environmental Agency of Banjar Regency through the Head of the Environmental Service of the District. Banjar says:

"If the supervisory task was taken over by the Control Division because it was in accordance with their main function, yesterday they immediately moved when they knew that Banjarbaru had implemented a guardianship. But just checking the plastic bag, if now there is already a circular not to provide plastic bags for some Alfamart and Indomaret"(interview: Wednesday, November 11, 2020).

He also added that this policy was still not fully implemented because there were still many obstacles, especially in the content of the policy itself which had to be revised. As a result, the supervision carried out by the Environmental Monitoring Section is only about checking the types of plastic bags used and if there is a modern store that provides plastic bags that are not environmentally friendly, they are likely to receive a warning without withdrawing or confiscating the nonenvironmentally friendly plastic bag.

The circular is distributed to Alfamart and Indomaret, but not all Alfamart and Indomaret outlets have the letter. Of the 3 Alfamart outlets that the researchers visited, based on the results of observations on November 13, 2020, only 1 Alfamart outlet in Peat District had a circular, circular or appeal affixed to the front glass of the outlet so that visitors could also see and read that Banjar Regency have started implementing regulations on reducing the use of plastic bags. Likewise with the Indomaret outlet, of the 3 outlets that were visited only 1 outlet, namely in Kertak Hanyar District, which has a circular. This circular in Indomaret is only well known by the employees, so it is only posted about 2 weeks near the cashier.

After this supervision, each of the modern shops implements different policies. Two of them, namely on the Indomaret side, the policy set was to no longer provide plastic bags and was diverted to offer environmentally friendly shopping bags for consumers in need. Meanwhile, the policy implemented by Alfamart is to provide plastic bags but pay Rp. 200. 
Eka Yusnitawati et al., Sch Int J Law Crime Justice, Feb, 2021; 4(2): 110-116

Observations on November 12, 2020 at one of the Indomaret outlets, Kertak Hanyar District. The researcher saw that every visitor who went to the cashier after making a payment was no longer offered or given a plastic bag. Many of the visitors who may already be aware of the policy to reduce the use of plastic bags choose to bring plastic bags or personal eco-friendly bags. While the results of observations on November 13, 2020 at one of Alfamart outlets in Peat District, researchers saw that even though the policy decided by Alfamart was to pay Rp. 200 for each plastic bag, Alfamart cashiers did not offer visitors to buy plastic bags.

There are differences in policies regarding these plastic bags, according to the Head of the Environment Agency, Kab. Absolute Banjar is the policy of each modern shop in reducing the use of plastic bags, not based on recommendations from the local government.

During 2019 the Environmental Monitoring Section visited approximately 15 modern shops. However, there are still modern shops and the people of Banjar Regency who do not know that the government has supervised several modern shops in Banjar Regency. When researchers conducted interviews with employees of modern stores, only a few knew that the government had supervised them. The following are the results of an interview with a modern shop:

An interview with Mr. R Crew Alfamart, Kertak Hanyar District explained:

"I don't really know about the supervision from the government, but our shop has implemented the rule. We don't give plastic bags to every consumer who shop anymore and if they ask us to charge $\mathrm{Rp}$. 200"(interview: 18 November 2020).

Interview with Mrs. Z, the Kasir Toko Gambut Mart, Gambut District said:

"Our shop has been visited by the government once, but they only look at the plastic bags we use. Then until now there has been no follow-up from the government." (Interview: 18 November 2020).

Interview with Mrs. R Kasir Indomaret Martapura Kota District said:

"If there is supervision, I don't know, mba, it just seems that the government has gone straight to our superiors, so far we have not received a circular about stopping the supply of plastic bags. Then from the boss to us he said we don't need to provide plastic bags anymore. If a visitor asks for a plastic bag, they will be told that we only sell environmentally friendly shopping bags." (interview: 19 November 2020).

Meanwhile, according to the people of Banjar Regency, to be precise, Mrs. H, one of the Kertak Hanyar people, said:
"Wow, I don't really know for supervision from the government, as long as I go to Alpha or Indo I have never seen it either" (interview: 18 November 2020).

In accordance with some of the results of the interviews above, the supervisory duties carried out by the local government are not very visible, because the majority of modern store employees do not know if the government is monitoring modern stores.

\section{Become a Facilitator}

According to the Banjar Regent Regulation No. 8 of 2016 concerning Reducing the Use of Plastic Bags, the facilitator is the government to facilitate the application of appropriate technology and results for the manufacture of environmentally friendly plastic bags.

The government's initial plan for the task of this facilitator was assigned to the Regional Public Service Agency for the Environmental Service of Banjar Regency to make an environmentally friendly plastic bag, which is easy to decompose when exposed to water and then distributed to modern shops or commodities that sell plastic bags. However, because this regulation has just been implemented, the task of the local government, especially the Banjar Regency Environmental Service, has not yet reached this stage. Head of the Head of the Environment Agency, Kab. Banjar says:

"Our target is to actually implement the Banjar Regency Perbup No. 8 of 2016 by 2020, so the task of this facilitator cannot be implemented. But we already have a design that specifically for the facilitator team is from the BLUD because it is in accordance with their main tasks and functions. Later, after BLUD makes an environmentally friendly plastic bag, maybe later it will also be taught to plastic bag producers how to make plastic bags that break down easily"(interview: Wednesday, November 11, 2020).

In addition, the Banjar Regency Environmental Service has not yet reached the stage of conceptualizing the facilitator team from the amount of human resources needed, the budget that needs to be prepared, the supporting facilities used in making environmentally friendly plastic bags and other factors related to the task.

The Environmental Agency of Banjar Regency also hopes that after the revision of the regulation on reducing the use of plastic bags, not only will it be involved in the task of the facilitator, but there must be a form of cooperation with various parties because the process of making environmentally friendly plastic bags is not easy. This is in accordance with the statement of the Head of the Environmental Office of the District. Banjar who said: 
Eka Yusnitawati et al., Sch Int J Law Crime Justice, Feb, 2021; 4(2): 110-116

"Hopefully, after a revision, the regulations are ready, other government agencies or the private sector can participate in collaborating in facilitating the manufacture of plastic bags" (interview: 11 November 2020).

When the task of this facilitator was asked of the community and employees of modern stores, the majority of them did not know if the government was the facilitator in making environmentally friendly plastic bags.

Interview with Mrs. R, the community of Kertak Hanyar District said:

"I have never heard that the government has provided training for making environmentally friendly plastic bags. But if, for example, there is hope like the plastic bag that I saw on TV yesterday, mba. The plastic crumbles easily when it hits water." (interview: 11 November 2020).

Interview with Mr. M Assistant Head of the Indomaret Store, Peat District, said:

"I haven't heard of you if the government is a facilitator to make plastic bags or environmentally friendly shopping bags. Yes, I hope that activity will be held." (interview: 12 November 2020).

Based on the results of the above research, it can be concluded that the task of the government as a facilitator has not been running at all, because the regulations for reducing plastic bags in 2019 have not been properly implemented, the government's task in 2019 only focuses on socialization and supervision activities in various modern shops.

\section{Conducting Coach}

The last task and responsibility of the Banjar Regency government in implementing the Banjar Regent Regulation No. 8 of 2016 is to provide guidance to business actors to reduce the use of plastic bags.

According to Poerwadarmita 2012, coaching is an effort, action and activity that is carried out in an efficient and effective manner to obtain better results. Likewise, the guidance carried out by the Banjar Regency government aims to change people's habits so that they can reduce the use of plastic bags so that the potential for environmental damage caused by plastic can be minimized [5].

However, until now this coaching has yet to take place. Head of the Head of the Environment Agency, Kab. Banjar says:

"We have not yet been able to carry out the training to reduce plastic bags for business actors, while the guidance we do is to provide insight and always remind the community and all related elements to be able to sort when disposing of waste. Organic waste, yes, throw it into the organic waste bin, dispose of inorganic waste into the inorganic trash"(interview: Wednesday, November 11, 2020)

According to him, if that alone has been used continuously by the people of Banjar Regency, the target to be achieved by the Environmental Service of Banjar Regency in terms of solid waste will be fulfilled because it is supported by the knowledge and habits of the people of Banjar Regency to dispose of waste according to the type of place. He also added that before getting to the stage of reducing the use of plastic bags, people must first be able to distinguish between the types of waste when disposing of them. In line with the sentence conveyed by the Head of the PPSL DLH Kab. Banjar, according to one of Mr. A, the people of Kertak Hanyar District said:

"In my opinion, it is actually a bit complicated with this policy. The problem is that the important thing is for the community to dispose of garbage in the place and know the types of waste, so throw it in the type of trash. And what I have seen in my environment is that some people are already aware of the types of waste." (interview: 11 November 2020).

According to him, when people are used to disposing of garbage in its place, it will make it easier and reduce the burden on the government, especially the Environmental Service, regarding the authority to sort waste.

\section{CONCLUSSION}

From the results of the research that has been conducted, it is concluded that the implementation of Regent Regulation Number 08 of 2016 concerning Reducing the Use of Plastic Bags consists of 4 stages, namely socialization, facilitation, coaching and supervision. The implementation of Regent Regulation Number 8 of 2016 is considered ineffective because not all stages have been implemented.

\section{Suggestion}

The implementation of Regent Regulation No.8 of 2016 concerning Reducing the use of plastic bags in Banjar Regency should not only be borne by the district government, but law enforcement must also be carried out against people who violate the regulation, so that in addition to the district being clean but residents are also educated to obey the law.

\section{REFERENCE}

1. Kandziora, J.H., Van Toulon, N., Sobral, P., Taylor, H.L., Ribbink, A.J., Jambeck, J.R. and Werner, S. (2019). The important role of marine debris networks to prevent and reduce ocean plastic pollution. Marine pollution bulletin, 141, 657-662. 
Eka Yusnitawati et al., Sch Int J Law Crime Justice, Feb, 2021; 4(2): 110-116

2. Sununianti, V.V. (2015). Boenthelan sebagai upaya mengurangi sampah kantong plastik: kajian ekofeminisme. Jurnal Lingkungan dan Pembangunan, 1(3), pp.227-239.

3. Triestiyanto, B. W. (2019). Pengelolaan Sampah di Kabupaten Banjar. Banjar: Dinas Lingkungan Hidup Kabupaten Banjar.
4. Winoto, A. (2019). Sampah Masuk TPA Cahaya Kencana. Banjar: Unit Pelaksana Teknis Daerah (UPTD) TPA Cahaya Kencana.

5. Banjar, D. L. (2019). Produksi Sampah di Kabupaten Banjar 2014-2018. Banjar: BLUD Intan Hijau, Dinas Lingkungan Hidup Kabupaten Banjar. 